\title{
Implementasi Fuzzy Inference System untuk Menentukan Alat Kontrasepsi Program Keluarga Berencana
}

\author{
Vivin Ayu Lestari*, Eka Larasati Amalia \\ Teknologi Informasi, Politeknik Negeri Malang, \\ Jl. Soekarno Hatta No. 9 Malang \\ *e-mail: vivin@polinema.ac.id
}

(received: 22 Desember 2020, revised: 27 Desember 2020, accepted: 1 Januari 2021)

\begin{abstract}
Abstrak
Program keluarga berencana merupakan salah satu kebijakan pemerintah untuk mengatur pertumbuhan penduduk di Indonesia. Untuk mendukung hal tersebut pemerintah membuat pelayanan kontrasepsi yang merupakan salah satu jenis layanan program keluarga berencana. Banyak sekali faktor-faktor yang mempengaruhi akseptor dalam memilih alat kontrasepsi yang sesuai, diantaranya adalah faktor ekonomi, kesehatan dan lain sebagainya. Hal ini menjadikan tidak semua alat kontrasepsi cocok digunakan oleh akseptor. Oleh karena it perlu dibuat sebuah sistem untuk membantu akseptor ketika memilih alat kontrasepsi yang digunakan. Metode Fuzzy Inference System merupakan salah satu algoritma yang bisa digunakan untuk membantu pengambilan keputusan. Parameter yang digunakan untuk fungsi keanggotaan fuzzy dalam penelitian ini adalah umur, frekuensi sanggama, status kesehatan, efektivitas, harga, dan jangka waktu. hasil perhitungan korelasi spearman didapatkan nilai korelasi 0,606, sehingga menurut tabel korelasi spearman hasil korelasinya termasuk kategori kuat, sehingga dapat digunakan untuk membantu merekomendasikan pemilihan alat kontrasepsi yang sesuai untuk masing-masing akseptor.
\end{abstract}

Kata Kunci: alat kontrasepsi, keluarga berencana, fuzzy inference system, korelasi ranking spearman

\begin{abstract}
The family planning program is one of the government policies to regulate population growth in Indonesia. To support this, the government makes contraceptive services which are one type of family planning program service. There are many factors that influence the acceptor in choosing the appropriate contraceptive device, including economic factors, health and so on. This makes not all contraceptives suitable for use by the acceptors. Therefore, it is necessary to create a system to help the acceptors when choosing the contraceptive device to use. The Fuzzy Inference System method is an algorithm that can be used to help decision-making. The parameters used for the fuzzy membership function in this study are age, frequency of intercourse, health status, effectiveness, price, and time period. The results of the calculation of the Spearman correlation obtained a correlation value of 0.606, so according to the Spearman correlation table, the result of the correlation is in the strong category, so that it can be used to help recommend the selection of suitable contraceptives for each acceptor.
\end{abstract}

Keywords: contraception, family planning, fuzzy inference system, spearman rank correlation

\section{Pendahuluan}

Keluarga berencana adalah program pemerintah dalam usaha untuk mewujudkan kesejahteraan masyarakat dengan cara mengatur jarak kehamilan dengan menggunakan alat kontrasepsi dengan tujuan umum dari program keluarga berencana adalah mencegah kehamilan, mengatur jarak kehamilan dan membatasi jumlah anak [1]. Pelayanan kontrasepsi adalah salah satu jenis layanan program keluarga berencana, kebanyakan orang memilih dan menggunakan berbagai metode alat kontrasepsi yang tersedia. Alat kontrasepsi memang sangat berguna sekali dalam program keluarga berencana namun perlu diketahui bahwa tidak semua alat kontrasepsi cocok dengan kondisi setiap orang [2]. Berdasarkan hal tersebut maka setiap pribadi harus bisa memilih alat kontrasepsi yang cocok untuk dirinya. Salah satu cara optimalisasi manfaat kesehatan KB adalah menyediakan 
pelayanan kesehatan bagi pasangan keluarga berencana untuk memenuhi kebutuhan pelayanan kesehatan reproduksi utama.

Banyak pasangan yang mengalami kesulitan ketika menentukan pilihan alat kontrasepsi yang akan digunakan [3]. Hal ini tidak hanya disebabkan karena keterbatasan jumlah metode yang tersedia, tetapi juga karena tidak semua alat kontrasepsi selalu cocok untuk semua orang, sehingga mereka harus memiliki pengetahuan yang luas tentang kelebihan dan kekurangan masing-masing alat kontrasepsi. Selain itu setiap pasangan harus mempertimbangkan penggunaan alat kontrasepsi secara rasional, efektif dan efisien. Namun demikian, meskipun telah mempertimbangkan untung rugi semua alat kontrasepsi yang tersedia, akan tetapi masih terdapat kesulitan untuk mengontrol fertilisasi secara aman, efektif, dengan metode yang dapat diterima baik secara perseorangan maupun ditingkat reproduksi [4]. Selain itu untuk beberapa pasangan selain mempertimbangkan hal-hal tersebut, mereka juga mempertimbangkan harga atau biaya yang dikeluarkan selama penggunaan alat kontrasepsi tersebut [5].

Berdasarkan permasalahan tersebut, maka perlu untuk menemukan upaya untuk memecahkan masalah ini. Salah satu cara adalah membangun sebuah sistem yang bisa mempermudah pasangan keluarga berencana untuk menentukan alat kontrasepsi yang sesuai. Dalam pembangunan sistem tersebut diperlukan sebuah metode agar hasilnya dapat memberikan solusi secara akurat dan objektif. Penulis membuat suatu sistem yang digunakan untuk menentukan alat kontrasepsi yang sesuai bagi keluarga berencana menggunakan metode Fuzzy Inference System. Metode ini dipilih karena mempunyai kelebihan yaitu dapat mendefinisikan nilai yang kabur dari inputan penilaian, membangun, dan mengaplikasikan pengalaman-pengalaman dari pakar-pakar secara langsung sehingga tidak melalui proses pelatihan [6]. Metode fuzzy inference system yang akan mempresentasikan suatu himpunan fuzzy dengan fungsi keanggotaan dan variabel yang akan digunakan ada 6 yaitu umur, frekuensi sanggama, status kesehatan, efektivitas, harga dan jangka waktu. Sedangkan untuk output yang digunakan dalam penelitian ini adalah kondom, pil KB, suntik, implant, IUD, dan Kontrasepsi Mantap (kontap). Pada sistem ini nantinya diharapkan dapat memberikan solusi yang efektif ketika menentukan alat kontrasepsi yang sesuai dengan kondisi pasangan.

\section{Tinjauan Literatur}

\subsection{Penelitian Terdahulu}

Penelitian dilakukan dengan cara melakukan studi literatur terlebih dahulu diantaranya adalah metode penelitian yang sebelumnya digunakan adalah AHP (Analytical Hierarchy Process) untuk menentukan alat kontrasepsi [7]. Penelitian tersebut dilakukan dengan penilaian tingkat prioritas dan variabel-variabel yang diinginkan dengan membuat hierarki dari semua variable yang ada. Dengan menggunakan sistem ini menghasilkan sistem pengambil keputusan penentuan alat kontrasepsi berdasarkan peringkat (ranking) sebagai solusi pemilihannya. Suntik mempunyai bobot 0.3587 , pil 0.2701 , kondom 0.1685, iud/spiral 0.1185, dan implant dengan bobot 0.0842. Dalam penelitian ini belum memaksimalkan mengelola data dan pemberian bobot/prioritas sehingga terjadi Inconsistency pada Pairwise Comparisons (Perbandingan Berpasangan). Penelitian Simargolang dkk menjelaskan bahwa metode fuzzy terbukti efektif dalam membantu memilih calon presiden mahasiswa di universitas sehingga dapat membantu panitia untuk mengelola data yang ada [8]. Pada penelitian Syawalia dkk tentang implementasi fuzzy pada sistem sortir otomatis alat perhitungan jumlah buah apel [9]. Dalam penelitian tersebut diperoleh akurasi dengan tingkat keberhasilan 90\%. Pada penelitian lain metode fuzzy juga digunakan untuk menetukan penggandaan perangkat teknologi informasi di PT Kojo Balairaja [10]. Berdasarkan implementasi metode fuzzy yang digunakan dalam penelitian tersebut sistem yang dibangun dapat membantu manajer pada PT. Kojo Balairaja dalam pengambilan keputusan pengadaan perangkat teknologi informasi sesuai dengan kriteria kelayakan yaitu manajer dapat menyetujui, mempertimbangkan dan menolak permintaan perangkat, kualitas dan kemutakhiran perangkat yang dibutuhkan serta dapat memprediksi biaya yaitu kualitasnya bagus tetapi harga sedang dan terjangkau oleh perusahaan. Penelitian dengan mengimplementasikan metode fuzzy juga dapat digunakan dalam menentukan tingkat kriminalitas di kota Batam [11]. Hasilnya adalah pengujian sistem ini memiliki tingkat akurasi yang tinggi sehingga bisa diterapkan dalam pengambilan keputusan Tingkat kriminalitas di Kota Batam. Selain itu penelitian lainnya yang 
menggunakan metode fuzzy adalah untuk menentukan jumlah pembelian produk berdasarkan data persediaan dan penjualan [12] dengan hasil bahwa metode tersebut mencapai nilai kebenaran $44,49656 \%$ dalam menentukan jumlah pembelian untuk persediaan produk suatu perusahaan. Selain itu metode ini juga dapat membantu dalam menentukan jumlah pembelian produk untuk persediaan pada bulan berikutnya.

\subsection{Alat Kontrasepsi}

Dalam program KB pemilihan alat kontrasepsi sangat penting, tetapi tidak semua alat kontrasepsi sesuai dengan kondisi setiap orang. Hal ini menjadikan pentingnya memilih alat kontrasepsi yang cocok untuk setiap pasangan [2] . Metode kontrasepsi dapat diklasifikasikan ke dalam 2 kelompok yaitu metode kontrasepsi jangka panjang (MKJP) dan non MKJP. Di semua pengaturan, Non MKJP lebih umum digunakan daripada metode MKJP, meskipun metode MKJP lebih efektif, lebih hemat biaya, dan lebih ditoleransi daripada Non MKJP [13]. Kedua jenis alat kontrasepsi tersebut memiliki efek samping yang berbeda-beda terhadap penggunaanya diantaranya yaitu pertumbuhan jerawat, penambahan berat badan, pola haid yang tidak teratur, nyeri keputihan, infeksi, rambut rontok dan kesuburan kembali lama setelah tidak menggunakannya.

Memilih metode kontrasepsi bukanlah suatu hal yang mudah karena efek yang berdampak terhadap tubuh tidak akan diketahui selama belum menggunakannya [7]. Tidak ada metode kontrasepsi yang aman dan efektif untuk semua orang, karena setiap individu memiliki kecocokan dan kesesuaian yang berbeda [4], namun beberapa persyaratan alat kontrasepsi yang ideal [3] adalah (1) aman tidak menimbulkan komplikasi jika digunakan, (2) mempunyai daya guna tinggi sehingga dapat mencegah kehamilan ketika digunakan, (3) dapat diterima oleh klien, lingkungan dan budaya masyarakat, (4) Harganya terjangkau, dan (5) Jika penggunaannya dihentikan, maka pengguna akan kembali subur kecuali alat kontrasepsi mantap.

\subsection{Fuzzy Inference System}

Logika fuzzy adalah logika yang berdasar pada teori himpunan fuzzy. Himpunan fuzzy menyatakan bahwa derajat keanggotaan dari suatu elemen himpunan terdiri antara rentang 0 sampai 1 [14].

Setiap konsekuen pada aturan yang berbentuk IF-THEN harus direpresentasikan dengan suatu himpunan fuzzy dengan fungsi keanggotaan yang monoton.Hasil outputnya adalah inferensi dari masing-masing aturan diberikan secara tegas berdasarkan $\alpha$-predikat. Proses agregasi antar aturan dilakukan, dan hasil akhirnya diperoleh dengan menggunakan defuzzy dengan konsep rata-rata terbobot.

\section{Metode Penelitian}

\subsection{Formulasi Permasalahan}

Sebelum dilakukan perhitungan sistem inferensi fuzzy, maka dilakukan terlebih dahulu pengambilan data observasi penggunaan alat kontrasepsi. Tabel 1 berikut ini menyajikan data dari hasil wawancara dengan tenaga kesehatan kebidanan yang akan dijadikan nilai inputan dari setiap kriteria.

Variabel yang digunakan ada 6 yaitu umur, frekkuensi sanggama, status kesehatan, efektifitas, harga, dan jangka waktu. Umur merupakan rentang usia pengguna alat kontrasepsi dalam program Keluarga Berencana. Frekuensi sanggama adalah jumlah banyaknya sanggama setiap pasangan dalam berhubungan setiap harinya. Status kesehatan merupakan kondisi kesehatan pengguna ketika berkonsultasi untuk melakukan pemilihan alat kontrasepsi yang sesuai. Efektivitas adalah keefektifan alat kontrasepsi yang digunakan dalam pencegahan kehamilan. Harga merupakan biaya yang dikeluarkan dalam penggunaan alat kontrasepsi tersebut. Sedangkan jangka waktu adalah waktu pemakaian/konsumsi alat kontrasepsi. 
Tabel 1. Contoh Kasus Permasalahan Pada Fuzzy Inference System

\begin{tabular}{llll}
\hline No & \multicolumn{1}{c}{ Variabel } & Nilai & \multicolumn{1}{c}{ Satuan } \\
\hline 1 & Umur & 28 & Tahun \\
2 & Frekuensi Sanggama & 5 & Kali/hari \\
3 & Status Kesehatan & 1 & Normal/Tidak normal \\
4 & Efektivitas & 7 & Baik/tidak baik \\
5 & Harga & 15 & Ribu rupiah \\
6 & Jangka waktu & 30 & Hari \\
\hline
\end{tabular}

\subsection{Himpunan Fuzzy}

Himpunan fuzzy adalah himpunan yang derajat keanggotaan tiap elemennya berada dalam rentang 0 sampai 1[15]. Pada penelitian ini digunakan himpunan fuzzy dengan dua nilai linguistik untuk masing-masing kriteria yang disajikan pada Tabel 2 berikut ini.

Tabel 2. Himpunan Fuzzy

\begin{tabular}{ll}
\hline \multicolumn{1}{c}{ Himpunan } & Fuzzy \\
\hline Variabel Input & Nilai Linguistik \\
\hline Umur & Muda \\
& Tua \\
Frekuensi sanggama & Sedikit \\
Status kesehatan & Banyak \\
& Buruk \\
Efektivitas & Baik \\
& Buruk \\
Harga & Baik \\
& Murah \\
Jangka waktu & Mahal \\
& Singkat \\
Alat kontrasepsi & Lama \\
& Pil \\
& Suntik \\
& Implant \\
& Kondom \\
& IUD \\
& Kontrasepsi \\
\hline
\end{tabular}

\subsection{Fuzzyfikasi}

Fuzzyfikasi adalah proses perhitungan nilai input menjadi dearajat keanggotaan yang berdasarkan batas-batas fungsi keanggotaan [16]. Berikut ini adalah fungsi keanggotaan himpunan fuzzy dengan 6 kriteria input:

a. Himpunan fuzzy umur

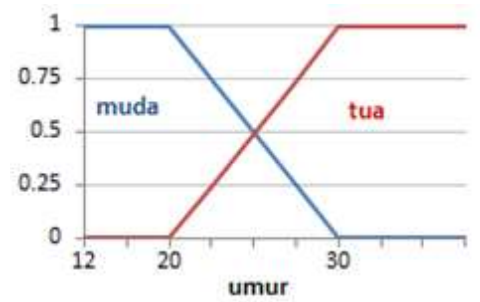

Gambar 1. Himpunan Fuzzy Umur 
Derajat keanggotaan muda:

$\mu_{\text {uтur muda }}(x)=\left\{\begin{aligned} 1 ; & ; x \leq 20 \\ \frac{30-x}{30-20} ; & 20<x<30 \\ 0 ; & x \geq 30\end{aligned}\right.$

Derajat keanggotaan tua:

$\mu_{\text {umur tua }}(x)=\left\{\begin{aligned} 1 ; & ; x \geq 30 \\ \frac{x-20}{30-20} ; & 20<x<30 \\ 0 ; & x \leq 20\end{aligned}\right.$

b. Himpunan fuzzy frekuensi sanggama

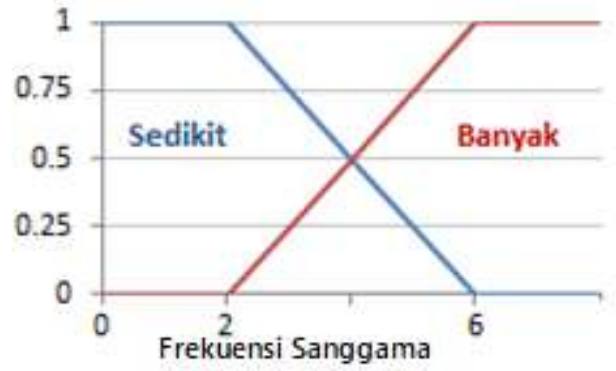

\section{Gambar 2. Himpunan Fuzzy Frekuensi Sanggama}

Derajat keanggotaan sedikit:

$\mu_{\text {frekuensi sanggama sedikit }}(x)=\left\{\begin{array}{c}1 ; x \leq 2 \\ \frac{6-x}{6-2} ; 2<x<6 \\ 0 ; x \geq 6\end{array}\right.$

Derajat keanggotaan banyak:

$\underset{\substack{\text { frekuensi sanggama } \\ \text { banyak }}}{\mu_{\text {frat }}}(x)=\left\{\begin{array}{c}1 ; x \geq 6 \\ \frac{x-2}{6-2} ; 2<x<6 \\ 0 ; x \leq 2\end{array}\right.$

c. Himpunan fuzzy status kesehatan

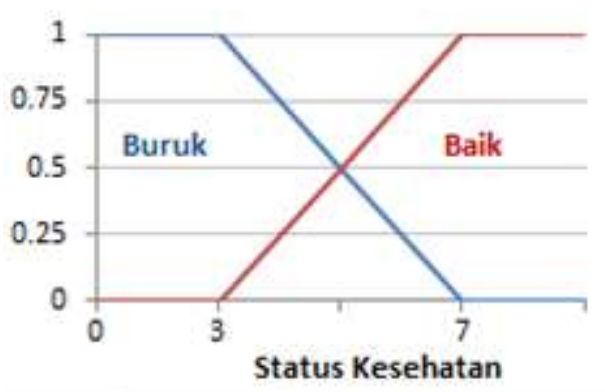

Derajat keanggotaan buruk:

\section{Gambar 3. Himpunan Fuzzy Status Kesehatan}

$\mu_{\text {status kesehatan buruk }}(x)=\left\{\begin{array}{c}1 ; x \leq 3 \\ \frac{7-x}{7-3} ; 3<x<7 \\ 0 ; x \geq 7\end{array}\right.$ 
Derajat keanggotaan baik:

$\mu_{\text {status kesehatan baik }}(x)=\left\{\begin{array}{c}1 ; x \geq 7 \\ \frac{x-3}{7-3} ; 3<x<7 \\ 0 ; x \leq 3\end{array}\right.$

d. Himpunan fuzzy efektivitas

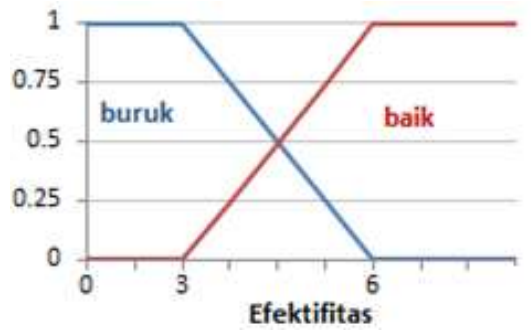

Derajat keanggotaan buruk:

\section{Gambar 4. Himpunan Fuzzy Efektivitas}

$\mu_{\text {efektivitas buruk }}(x)=\left\{\begin{array}{c}1 ; x \leq 3 \\ \frac{6-x}{6-3} ; 3<x<6 \\ 0 ; x \geq 6\end{array}\right.$

Derajat keanggotaan baik:

$\mu_{\text {efektivitas baik }}(x)=\left\{\begin{array}{c}1 ; x \geq 6 \\ \frac{x-3}{6-3} ; 3<x<6 \\ 0 ; x \leq 3\end{array}\right.$

e. Himpunan fuzzy harga

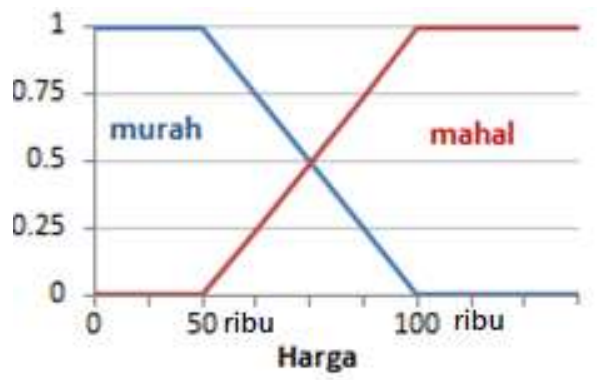

Derajat keanggotaan murah:

\section{Gambar 5. Himpunan Fuzzy Harga}

$\mu_{\text {harga murah }}(x)=\left\{\begin{aligned} 1 & ; x \leq 50 \\ \frac{100-x}{100-50} ; & 50<x<100 \\ 0 ; & x \geq 100\end{aligned}\right.$

Derajat keanggotaan mahal:

$\mu_{\text {harga mahal }}(x)=\left\{\begin{aligned} 1 ; & x \geq 100 \\ \frac{x-50}{100-50} ; & 50<x<100 \\ 0 ; & x \leq 50\end{aligned}\right.$

f. Himpunan fuzzy jangka waktu

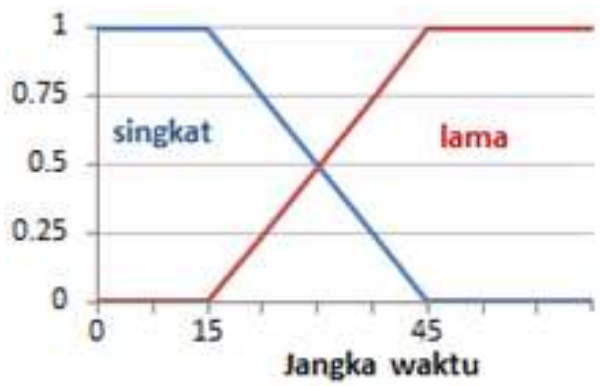

Gambar 5. Himpunan Fuzzy Jangka Waktu

http://sistemasi.ftik.unisi.ac.id 
Derajat keanggotaan singkat:

$\underset{\text { singkat }}{\mu_{\text {jangka waktu }}(x)}=\left\{\begin{aligned} 1 & ; x \leq 15 \\ \frac{45-x}{45-15} ; & 15<x<45 \\ 0 ; & x \geq 45\end{aligned}\right.$

Derajat keanggotaan lama:

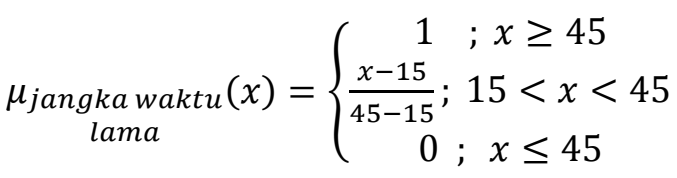

g. Output

Rekomendasi alat kontrasepsi yang digunakan dalam penelitian ini disajikan pada Tabel 3.

Tabel 3. Pilihan Alat Kontrasepsi

\begin{tabular}{ll}
\hline No & \multicolumn{1}{c}{ Alat Kontrasepsi } \\
\hline 1 & Pil \\
2 & Suntik \\
3 & Implant \\
4 & Kondom \\
5 & IUD \\
6 & Kontrasepsi mantap (kontap) \\
\hline
\end{tabular}

\subsection{Sistem Inferensi Fuzzy}

Sistem Inferensi Fuzzy adalah proses perhitungan berdasarkan teori himpunan fuzzy, aturan fuzzy, dan konsep logika fuzzy [16]. Sebelum melakukan perhitungan inference system maka dilakukan penentuan basis aturan atau rule base. Pada penelitian ini terdiri dari 64 rule base, berikut ini contoh rule base yang disajikan pada Tabel 4.

Tabel 4. Basis Aturan atau Rule Base

\begin{tabular}{cccccccc}
\hline Rule & Umur & Frekuensi & Status & Efektivitas & Harga & Jangka & Keputusan \\
\hline 1 & Muda & Sedikit & Buruk & Buruk & Murah & Singkat & Kondom \\
2 & Muda & Sedikit & Buruk & Buruk & Murah & Lama & Suntik \\
3 & Muda & Sedikit & Buruk & Buruk & Mahal & Singkat & Pil \\
4 & Muda & Sedikit & Buruk & Buruk & Mahal & Lama & Kondom \\
5 & Muda & Sedikit & Buruk & Baik & Murah & Singkat & Kondom \\
6 & Muda & Sedikit & Buruk & Baik & Murah & Lama & Pil \\
7 & Muda & Sedikit & Baik & Baik & Mahal & Singkat & IUD \\
8 & Muda & Sedikit & Baik & Baik & Mahal & Lama & Kontap \\
9 & Muda & Sedikit & Baik & Buruk & Murah & Singkat & Kondom \\
10 & Muda & Sedikit & Baik & Buruk & Murah & Lama & Suntik \\
$\ldots$. & $\ldots .$. & $\ldots .$. & $\ldots .$. & $\ldots .$. & $\ldots \ldots$ & $\ldots .$. & $\ldots$. \\
64 & Tua & Banyak & Baik & Baik & Mahal & Lama & IUD \\
\hline
\end{tabular}

Pada proses selanjutnya adalah dilakukan perhitungan fuzzy inference system berdasarkan masing-masing rule base yang telah di fuzzyfikasikan. Pada Tabel 5 disajikan hasil perhitungan fuzzy inference system berdasarkan masing-masing rulebase yang telah di fuzzyfikasikan. Kemudian dilakukan perhitungan alfa predikat yang digunakan sebagai dasar untuk pengambilan keputusan rekomendasi alat kontrasepsi yang digunakan oleh akseptor. Alfa predikat tersebut diambil dari nilai minimal hasil fuzzyfikasi pada setiap rulebase. 
Tabel 5. Penghitungan Inferensi Fuzzy

\begin{tabular}{|c|c|c|c|c|c|c|c|}
\hline Rule & Umur & $\begin{array}{l}\text { Frekuensi } \\
\text { Senggama }\end{array}$ & Status kesehatan & Efektivitas & Harga & Jangka waktu & $\alpha$-predikat \\
\hline 1 & 0.2 & 0.25 & 1 & 0 & 1 & 0.5 & 0 \\
\hline 2 & 0.2 & 0.25 & 1 & 0 & 1 & 0.5 & 0 \\
\hline 3 & 0.2 & 0.25 & 1 & 0 & 0 & 0.5 & 0 \\
\hline 4 & 0.2 & 0.25 & 1 & 0 & 0 & 0.5 & 0 \\
\hline 5 & 0.2 & 0.25 & 1 & 1 & 1 & 0.5 & 0.2 \\
\hline 6 & 0.2 & 0.25 & 1 & 1 & 1 & 0.5 & 0.2 \\
\hline 7 & 0.2 & 0.25 & 0 & 1 & 0 & 0.5 & 0 \\
\hline 8 & 0.2 & 0.25 & 0 & 1 & 0 & 0.5 & 0 \\
\hline 9 & 0.2 & 0.25 & 0 & 0 & 1 & 0.5 & 0 \\
\hline 10 & 0.2 & 0.25 & 0 & 0 & 1 & 0.5 & 0 \\
\hline 11 & 0.2 & 0.25 & 0 & 0 & 0 & 0.5 & 0 \\
\hline 12 & 0.2 & 0.25 & 0 & 0 & 0 & 0.5 & 0 \\
\hline 13 & 0.2 & 0.25 & 0 & 1 & 1 & 0.5 & 0 \\
\hline 14 & 0.2 & 0.25 & 0 & 1 & 1 & 0.5 & 0 \\
\hline 15 & 0.2 & 0.25 & 0 & 1 & 0 & 0.5 & 0 \\
\hline 16 & 0.2 & 0.25 & 0 & 1 & 0 & 0.5 & 0 \\
\hline 17 & 0.2 & 0.75 & 1 & 0 & 1 & 0.5 & 0 \\
\hline 18 & 0.2 & 0.75 & 1 & 0 & 1 & 0.5 & 0 \\
\hline 19 & 0.2 & 0.75 & 1 & 0 & 0 & 0.5 & 0 \\
\hline 20 & 0.2 & 0.75 & 1 & 0 & 0 & 0.5 & 0 \\
\hline 21 & 0.2 & 0.75 & 1 & 1 & 1 & 0.5 & 0.2 \\
\hline 22 & 0.2 & 0.75 & 1 & 1 & 1 & 0.5 & 0.2 \\
\hline 23 & 0.2 & 0.75 & 1 & 1 & 0 & 0.5 & 0 \\
\hline 24 & 0.2 & 0.75 & 1 & 1 & 0 & 0.5 & 0 \\
\hline 25 & 0.2 & 0.75 & 0 & 0 & 1 & 0.5 & 0 \\
\hline 26 & 0.2 & 0.75 & 0 & 0 & 1 & 0.5 & 0 \\
\hline 27 & 0.2 & 0.75 & 0 & 0 & 0 & 0.5 & 0 \\
\hline 28 & 0.2 & 0.75 & 0 & 0 & 0 & 0.5 & 0 \\
\hline 29 & 0.2 & 0.75 & 0 & 1 & 1 & 0.5 & 0 \\
\hline 30 & 0.2 & 0.75 & 0 & 1 & 1 & 0.5 & 0 \\
\hline 31 & 0.2 & 0.75 & 0 & 1 & 0 & 0.5 & 0 \\
\hline 32 & 0.2 & 0.75 & 0 & 1 & 0 & 0.5 & 0 \\
\hline 33 & 0.8 & 0.25 & 1 & 0 & 1 & 0.5 & 0 \\
\hline 34 & 0.8 & 0.25 & 1 & 0 & 1 & 0.5 & 0 \\
\hline 35 & 0.8 & 0.25 & 1 & 0 & 0 & 0.5 & 0 \\
\hline 36 & 0.8 & 0.25 & 1 & 0 & 0 & 0.5 & 0 \\
\hline 37 & 0.8 & 0.25 & 1 & 1 & 1 & 0.5 & 0.25 \\
\hline 38 & 0.8 & 0.25 & 1 & 1 & 1 & 0.5 & 0.25 \\
\hline 39 & 0.8 & 0.25 & 1 & 1 & 0 & 0.5 & 0 \\
\hline 40 & 0.8 & 0.25 & 1 & 1 & 0 & 0.5 & 0 \\
\hline 41 & 0.8 & 0.25 & 0 & 0 & 1 & 0.5 & 0 \\
\hline 42 & 0.8 & 0.25 & 0 & 0 & 1 & 0.5 & 0 \\
\hline 43 & 0.8 & 0.25 & 0 & 0 & 0 & 0.5 & 0 \\
\hline 44 & 0.8 & 0.25 & 0 & 0 & 0 & 0.5 & 0 \\
\hline 45 & 0.8 & 0.25 & 0 & 1 & 1 & 0.5 & 0 \\
\hline 46 & 0.8 & 0.25 & 0 & 1 & 1 & 0.5 & 0 \\
\hline 47 & 0.8 & 0.25 & 0 & 1 & 0 & 0.5 & 0 \\
\hline 48 & 0.8 & 0.25 & 0 & 1 & 0 & 0.5 & 0 \\
\hline 49 & 0.8 & 0.75 & 1 & 0 & 1 & 0.5 & 0 \\
\hline 50 & 0.8 & 0.75 & 1 & 0 & 1 & 0.5 & 0 \\
\hline 51 & 0.8 & 0.75 & 1 & 0 & 0 & 0.5 & 0 \\
\hline 52 & 0.8 & 0.75 & 1 & 0 & 0 & 0.5 & 0 \\
\hline 53 & 0.8 & 0.75 & 1 & 1 & 1 & 0.5 & 0.5 \\
\hline 54 & 0.8 & 0.75 & 1 & 1 & 1 & 0.5 & 0.5 \\
\hline 55 & 0.8 & 0.75 & 1 & 1 & 0 & 0.5 & 0 \\
\hline 56 & 0.8 & 0.75 & 1 & 1 & 0 & 0.5 & 0 \\
\hline 57 & 0.8 & 0.75 & 0 & 0 & 1 & 0.5 & 0 \\
\hline 58 & 0.8 & 0.75 & 0 & 0 & 1 & 0.5 & 0 \\
\hline 59 & 0.8 & 0.75 & 0 & 0 & 0 & 0.5 & 0 \\
\hline 60 & 0.8 & 0.75 & 0 & 0 & 0 & 0.5 & 0 \\
\hline 61 & 0.8 & 0.75 & 0 & 1 & 1 & 0.5 & 0 \\
\hline 62 & 0.8 & 0.75 & 0 & 1 & 1 & 0.5 & 0 \\
\hline 63 & 0.8 & 0.75 & 0 & 1 & 0 & 0.5 & 0 \\
\hline 64 & 0.8 & 0.75 & 0 & 1 & 0 & 0.5 & 0 \\
\hline
\end{tabular}

Pada penelitian ini, proses pengambilan keputusan dilakukan dengan cara perankingan alat kontrasepsi yang di ranking berdasarkan besar nilai alfa predikat pada hasil perhitungan fuzzy inference system. Pada awalnya dilakukan pengelompokan alfa predikat berdasarkan jenis alat 
kontrasepsi, kemudian nilai alfa predikat yang digunakan adalah yang tertinggi (maksimal) dari masing-masing alat kontrasepsi. Selanjutnya akan dilakukan proses perankingan dari ke 6 alat kontrasepsi yang diurutkan berdasarkan nilai alfa predikat tertinggi ke rendah. Tabel 5 disajikan hasil perangkingan alat kontrasepsi berdasarkan nilai alfa predikat.

Tabel 5. Perankingan Alat Kontrasepsi

\begin{tabular}{ccc}
\hline $\begin{array}{c}\text { Alat } \\
\text { Kontrasepsi }\end{array}$ & $\begin{array}{c}\text { a- } \\
\text { predikat }\end{array}$ & Ranking \\
\hline Pil & 0.5 & 1 \\
Suntik & 0.25 & 2 \\
Kondom & 0.2 & 3 \\
IUD & 0 & 5 \\
Kontap & 0 & 5 \\
Implan & 0 & 5 \\
\hline
\end{tabular}

\section{Hasil dan Pembahasan}

Berikut ini merupakan contoh hasil dari perhitungan menggunakan 3 data untuk menentukan pemilihan alat kontrasepsi yang disajikan pada Tabel 6. Data tersebut selanjutnya dijadikan inputan pada masing-masing kriteria atau variabel.

Tabel 6. Data Permasalahan Nyata Pemilihan Alat Kontrasepsi

\begin{tabular}{cccc}
\hline \multirow{2}{*}{ Variabel } & \multicolumn{3}{c}{ Nama Akseptor } \\
\cline { 2 - 4 } & Akseptor 1 & Akseptor 2 & Akseptor 3 \\
\hline Umur & 28 & 40 & 25 \\
Frekuensi sanggama & 5 & 3 & 3 \\
Status kesehatan & 1 & 5 & 6 \\
Efektivitas & 7 & 5 & 10 \\
Harga & 15 & 200 & 70 \\
Jangka waktu & 30 hari & 6 bulan (180 hari) & 30 hari \\
\hline
\end{tabular}

Tabel 7. Hasil Rekomendasi Alat Kontrasepsi

\begin{tabular}{|c|c|c|c|c|c|c|}
\hline \multirow{3}{*}{ AK } & \multicolumn{6}{|c|}{ Nama Akseptor } \\
\hline & \multicolumn{2}{|c|}{ Akseptor 1} & \multicolumn{2}{|c|}{ Akseptor 2} & \multicolumn{2}{|c|}{ Akseptor 3} \\
\hline & $\mathbf{R}$ & $\mathbf{R}^{\prime}$ & $\mathbf{R}$ & $\mathbf{R}^{\prime}$ & $\mathbf{R}$ & $\mathbf{R}^{\prime}$ \\
\hline Pil & 1 & 1 & 5 & 5 & 2 & 1 \\
\hline Suntik & 2 & 2 & 5 & 4 & 6 & 3 \\
\hline Kondom & 3 & 6 & 5 & 6 & 2 & 2 \\
\hline IUD & 5 & 3 & 3 & 3 & 4.5 & 5 \\
\hline Kontap & 5 & 5 & 1.5 & 1 & 4.5 & 6 \\
\hline Implan & 5 & 4 & 1.5 & 2 & 2 & 4 \\
\hline Koefisien korelasi & \multicolumn{2}{|c|}{0.6} & \multicolumn{2}{|c|}{0.93} & \multicolumn{2}{|c|}{0.53} \\
\hline
\end{tabular}

Pada Tabel 7 disajikan hasil rekomendasi alat kontrasepsi pada masing-masing akseptor, dimana $\mathrm{R}$ adalah rekomendasi menurut sistem dan R' adalah rekomendasi yang disarankan untuk pemilihan alat kontrasepsi. Untuk akseptor 1 diperoleh koefisien korelasi spearman sebesar 0.6 sehingga termasuk kategori korelasi kuat. Akseptor 2 mendapatkan nilai korelasi spearman sebesar 0.93 sehingga termasuk kategori korelasi hampir mendekati sempurna, sedangkan nilai korelasi akseptor 3 adalah 0.53 yang mempunyai korelasi kuat. 
Untuk mengetahui tingkat keakuratan hasil rekomendasi alat kontrasepsi dilakukan perhitungan akurasi sistem dengan jumlah data sebanyak 25 menggunakan koefisien korelasi spearman yang dinyatakan dalam persamaan 1 .

$r_{s}=1-\frac{6 \sum_{i-1}^{N} d_{i}^{2}}{N^{3}-N}$

Keterangan:

$\mathrm{r}_{\mathrm{s}}=$ ukuran sampel

$\mathrm{d}_{\mathrm{i}}=$ perbedaan antar kedua ranking

$\mathrm{N}$ = banyaknya observasi

Berikut ini perhitungan koefisien korelasi spearman untuk menentukan rekomendasi alat kontrasepsi:

$$
r_{s}=1-\frac{6 \times 32^{2}}{25^{3}-25}=1-\frac{6144}{15600}=0.606
$$

Menurut korelasi spearman untuk hasil perhitungan koefisien korelasi spearman untuk rekomendasi pemilihan alat kontrasepsi adalah 0.606 termasuk kategori korelasi kuat menurut tabel korelasi spearman yang disajikan pada Tabel 8.

Tabel 8. Korelasi Spearman [17]

\begin{tabular}{ll}
\hline Koefisien & Kekuatan Hubungan \\
\hline 0,00 & Tidak ada hubungan \\
$0,01-0,09$ & Hubungan kurang berarti \\
$0,10-0,29$ & Hubungan lemah \\
$0,30-0,49$ & Hubungan moderat \\
$0,50-0,69$ & Hubungan kuat \\
$0,70-0,89$ & Hubungan sangat kuat \\
\hline
\end{tabular}

\section{Kesimpulan}

Hasil penelitian yang telah dilakukan menunjukkan bahwa metode fuzzy inference system dapat digunakan untuk membantu menentukan alat kontrasepsi bagi akseptor keluarga berencana. Dari hasil perhitungan korelasi spearman dengan 25 data didapatkan nilai korelasi 0,606, sehingga menurut table korelasi spearman hasil korelasinya termasuk kategori kuat. Hal ini menunjukan adanya keterkaitan yang cukup tinggi antara ranking pakar dan hasil implementasi metode fuzzy inference system untuk pemilihan alat kontrasepsi, sehingga dapat digunakan untuk membantu merekomendasikan alat kontrasepsi yang sesuai oleh masing-masing pasangan.

\section{Referensi}

[1] D. Herowati and M. Sugiharto, "Hubungan antara Kemampuan Reproduksi, Kepemilikan Anak, Tempat Tinggal, Pendidikan dan Status Bekerja pada Wanita Sudah Menikah dengan Pemakaian Kontrasepsi Hormonal di Indonesia Tahun 2017," Bul. Penelit. Sist. Kesehat., vol. 22, no. 2, pp. 91-98, 2019, doi: 10.22435/hsr.v22i2.1553.

[2] R. Agustini, D. M. Wati, and A. Ramani, "Kesesuaian Penggunaan Alat Kontrasepsi Berdasarkan Permintaan KB pada Pasangan Usia Subur (PUS) di Kecamatan Puger Kabupaten Jember ( Contraceptives Use Compatibility Based on Contraceptive Demand Among Fertile Age Couple at Puger Sub District, Jember," e-Jurnal Pustaka Kesehatan, vol. 3, no. 1, pp. 155-162, 2015.

[3] S. Aryati, S. Sukamdi, and D. Widyastuti, "Faktor-Faktor yang Mempengaruhi Pemilihan Metode Kontrasepsi (Kasus di Kecamatan Seberang Ulu I Kota Palembang)," Maj. Geogr. Indones., vol. 33, no. 1, p. 79, 2019, doi: 10.22146/mgi.35474.

[4] Reva Dwi Yanty, "Faktor yang Mempengaruhi Pemilihan Jenis Kontrasepsi pada Wanita Usia 
Subur," J. Ilmiah Kesehatan Sandi Husada, vol. 10, no. 2, pp. 121-124, 2019, doi: 10.35816/jiskh.v10i2.127.

[5] M. Meilani and A. P. P. W. Tunggali, "Pemilihan Alat Kontrasepsi dalam Rahim (AKDR) pada akseptor Keluarga Berencana," Jurnal Kebidanan, vol. 9, no. 1, p. 31, 2020, doi: 10.26714/jk.9.1.2020.31-38.

[6] A. A. Syahidi, F. Biabdillah, and F. A. Bachtiar, "Perancangan dan Implementasi Fuzzy Inference System (FIS) Metode Tsukamoto pada Penentuan Penghuni Asrama," J. Teknol. Inf. dan Ilmu Komputer, vol. 6, no. 1, p. 55, 2019, doi: 10.25126/jtiik.2019611228.

[7] S. Yosefa, "Pemilihan Alat Kontrasepsi Yang Tepat pada Peserta KB dengan Menggunakan Metode AHP (Analitical Hierarky Process)," Menara Ilmu, vol. 14, no. 1, pp. 105-115, 2020.

[8] M. Y. Simargolang and H. S. Tamba, "Sistem Pendukung Keputusan Menggunakan Metode Fuzzy Sugeno untuk Menentukan Calon Presiden Mahasiswa di Universitas Asahan," $J$. Teknol. Inf., vol. 2, no. 2, p. 122, 2019, doi: 10.36294/jurti.v2i2.426.

[9] R. A. Syawalia, S. Rasyad, and D. A. Pratama, "Implementasi Fuzzy Logic pada Sistem Sortir Otomatis Alat Penghitung Jumlah Buah Apel," vol. 06, no. 02, pp. 421-432, 2020.

[10] R. Rajab, D. Defiariany, and F. Adiatma, "Sistem Pendukung Keputusan Pengadaan Perangkat Teknologi Informasi Menggunakan Metode Logic Fuzzy Pada PT. Kojo Balairaja," Indones. J. Comput. Sci., vol. 8, no. 1, pp. 1-10, 2019, doi: 10.33022/ijcs.v8i1.146.

[11] S. N. Rizki and H. Tipa, "Implementasi Fuzzy Inference System untuk Menentukan Tingkat Kriminalitas di Kota Batam," Digit. Zo. J. Teknol. Inf. dan Komun., vol. 10, no. 2, pp. 206221, 2020, doi: 10.31849/digitalzone.v10i2.3090.

[12] K. Harefa, "Penerapan Fuzzy Inference System untuk Menentukan Jumlah Pembelian Produk Berdasarkan Data Persediaan dan Penjualan," J. Inform. Univ. Pamulang, vol. 2, no. 4, 2017.

[13] E. Setiawati, O. W. K. Handayani, and A. Kuswardinah, "Pemilihan Kontrasepsi Berdasarkan Efek Samping pada Dua Kelompok Usia Reproduksi," Unnes J. Public Heal., vol. 6, no. 3, p. 167, 2017, doi: 10.15294/ujph.v6i3.11543.

[14] M. Yusida, D. Kartini, R. A. Nugroho, and M. Muliadi, "Implementasi Fuzzy Tsukamoto Dalam Penentuan Kesesuaian Lahan Untuk Tanaman Karet Dan Kelapa Sawit," Jurnal Klik: Kumpulan. Jurnal Ilmu Komputer, vol. 4, no. 2, pp. 233-246, 2017, doi: 10.20527/klik.v4i2.115.

[15] J. Nasir and J. Suprianto, "Analisis Fuzzy Logic Menentukan Pemilihan Motor Honda dengan Metode Mamdani,” J. Edik Inform., vol. 3, no. 2, pp. 177-187, 2017, [Online]. Available: http://dx.doi.org/10.22202/jei.2017.v3i2.1962.

[16] V. A. Lestari, I. Aknuranda, and F. Ramdani, "Usability evaluation of e-Government using ISO 9241 and Fuzzy Tsukamoto Approach," J. Telecommun. Electron. Comput. Eng., vol. 9, no. 2-8, pp. 153-157, 2017.

[17] N. R. Sari and W. F. Mahmudy, "Fuzzy Inference System Tsukamoto Untuk Menentukan Kelayakan Calon Pegawai," Seminar Nasional Sistem Informasi Indonesia, November, pp. 245-252, 2015. 